\title{
Review Article \\ Chitosan and Its Derivatives Applied in Harvesting Microalgae for Biodiesel Production: An Outlook
}

\author{
Guanyi Chen, ${ }^{1}$ Liu Zhao, ${ }^{1}$ Yun Qi, ${ }^{1}$ and Yuan-Lu Cui ${ }^{2}$ \\ ${ }^{1}$ School of Environment Science and Engineering, State Key Laboratory of Engines, Tianjin University, \\ No. 92 Weijin Road, Nankai District, Tianjin 300072, China \\ ${ }^{2}$ Tianjin State Key Laboratory of Modern Chinese Medicine, Tianjin University of Traditional Chinese Medicine, \\ Tianjin 300193, China
}

Correspondence should be addressed to Yun Qi; qiyun@tju.edu.cn

Received 6 February 2014; Accepted 10 March 2014; Published 9 April 2014

Academic Editor: Ranjit T. Koodali

Copyright (C) 2014 Guanyi Chen et al. This is an open access article distributed under the Creative Commons Attribution License, which permits unrestricted use, distribution, and reproduction in any medium, provided the original work is properly cited.

\begin{abstract}
Although oil-accumulating microalgae are a promising feedstock for biodiesel production, large-scale biodiesel production is not yet economically feasible. As harvesting accounts for an important part of total production cost, mass production of microalgae biodiesel requires an efficient low-energy harvesting strategy so as to make biodiesel production economically attractive. Chitosan has emerged as a favorable flocculating agent in harvesting of microalgae. The aim of this paper is to review current research on the application of chitosan and chitosan-derived materials for harvesting microalgae. This offers a starting point for future studies able to invalidate, confirm, or complete the actual findings and to improve knowledge in this field.
\end{abstract}

\section{Introduction}

Fossil fuels currently account for about $80 \%$ of global energy production. As demand for energy continues to increase, oil prices will rise and fossil fuels will be exhausted at some point in the future. Meanwhile, extensive utilization of fossil fuels has led to adverse effects including global climate change, environmental pollution, and public health problems [1].

Therefore, many countries have started to take series of measures to resolve this problem [2]. Identifying alternative renewable sources of fuel that are carbon neutral is important for many countries. Among the potential sources of renewable energy, biodiesel is of particular interest. Major advantages of biodiesel include mitigation of carbon dioxide emissions and potential use as a substitute for petroleum [3]. Biodiesel also has a higher energy density than competing biofuels measured in kilojoules per unit of mass. Furthermore, widespread adoption of biodiesel could improve urban air quality as emissions of carbon monoxide and volatile organic compounds are significantly lower than petroleumderived diesel. Biodiesel may become a primary energy source for sustainable development and could play a crucial role in the global energy infrastructure in the future. Energy security may drive biodiesel production as nations attempt to reduce their reliance on petroleum imports.

More than $95 \%$ of biodiesel sources are first generation agricultural edible crop oils [4] such as palm oil, oilseed rape, and soybean. However, these vegetable oils are also used for human consumption, which may lead to an increase in price of food-grade oils. Meanwhile, any transition to biodiesel production based upon these crops would require arable land, with a corresponding drop in other forms of agricultural productivity. In theory, it should be possible to produce low-cost biodiesel using nonedible oils (second generation biofuels), such as frying oils, animal fats, soap stocks, and grease. However, these nonedible oils are rarely available in quantities suitable for industrial-scale biodiesel production [5]. As a consequence, there is renewed interest in methods of producing biodiesel from microalgae.

As a promising feedstock for biodiesel production, microalgae offers compelling advantages compared to other oil crops: (1) the cultivation of microalgae does not need much land as terraneous plants [6]; indeed, biomass growth might not require any arable land at all if offshore farming proves feasible [7]; (2) microalgae have much higher biomass productivities than land plants; (3) some microalgae species 
are rich in oils; they can accumulate up to $20-50 \%$ (w/w DW) triacylglycerols [8] and certain strains may have content as high as $85 \%$ lipid under limited condition [9]; (4) microalgae utilize $\mathrm{CO}_{2}$ from the atmosphere via photosynthesis, offsetting greenhouse gas emissions; (5) microalgae require less freshwater for cultivation than terrestrial crops. Microalgae growth effectively removes nutrients, such as nitrogen and phosphorus, and heavy metals from wastewater; (6) biodiesel produced from microalgal oil has advantageous properties compared to standard biodiesel. These advances suggest that industrial production of biodiesel from microalgal oils may be feasible in the near future.

\section{Microalgae Harvest Strategy}

Although oil-accumulating microalgae are a promising feedstock for biodiesel production, large-scale biodiesel production is not yet economically feasible. This is mainly due to the high-energy inputs required for harvesting [10]. However, as microalgae' diameters are often as small as $3-30 \mathrm{~mm}$, harvesting the microalgae is a significant problem. In some commercial production systems, the culture broths are below $0.5 \mathrm{~kg} / \mathrm{m}^{3}$ dry biomass, which means that huge volumes need to be handed before algae oil can be extracted. Molina et al. estimated that harvesting can account for $20-30 \%$ of the total production cost [11]. Chisti even reported that the cost of the recovery process in his study contributed about $50 \%$ to the final cost of oil production [6].

Consequently, mass production of microalgae biodiesel acquires efficient low-energy harvesting strategy so as to make biodiesel production economically feasible. Microalgae can be harvested by centrifugation, filtration, flotation, sedimentation, and electrophoresis techniques [12].

Centrifugation can recover most microalgae from the liquid broth and is used in many commercial systems. Although centrifugation is effective, this process is energy intensive [13], which reduces the net energy return on investment (EROI) from the biodiesel produced from the microalgae, making this option less attractive both in financial and environmental terms. Norsker et al. calculated centrifugation required as much as $50 \%$ of the available energy in the recovered biomass [14]. From an energetic point of view, harvesting a large amount of microalgae using centrifugation is time consuming and costly [15]. Filtration is another option for harvesting cells, but this technology is only useful for the harvest of large species such as Spirulina but fails to recover small microalgae such as Chlorella or Scenedesmus [10].

Coagulation/flocculation processes offer high microalgae biomass recovery at reasonable costs [16]. These harvesting techniques have been successfully used in aquaculture, wastewater treatment, and removal of microalgae [10] and also reduce the net energy input required to produce biodiesel from microalgae feedstock.

Several flocculants have been developed to induce flocculation of microalgae cells that can be applied to the treatment of large amount of microalgae. According to their chemical compositions, there are two classifications of flocculants: inorganic flocculants and organic flocculants/polyelectrolyte flocculants [1].
The commonly used inorganic flocculants include ferric chloride $\left(\mathrm{FeCl}_{3}\right)$, aluminum sulfate $\left(\mathrm{Al}_{2}\left(\mathrm{SO}_{4}\right)_{3}\right)$, and ferric sulfate $\left(\mathrm{Fe}_{2}\left(\mathrm{SO}_{4}\right)_{3}\right)$ [17]. These multivalent metal salts are effective flocculants or coagulants and have been widely used to flocculate algal biomass. prepolymerized metal salts (such as polyaluminium chloride and polyferric sulfate) have proved to be efficient over a wider $\mathrm{pH}$ range [18]. However, flocculation by metal salts is not an appropriate method for cheap and sustainable harvesting of microalgae in largescale microalgae culture. This is because these flocculants are expensive and may produce large amounts of sludge, which can kill or prevent the growth of the microalgae and leave a residue in the water, and the excess cationic flocculant needs to be removed before it can be reused [19]. Another disadvantage of metal salts as flocculants is the concern about the human health, such as involvement in Alzheimer's disease and carcinogenesis [20-22].

The organic flocculants, such as synthetic polymeric flocculants and modified natural polymers, have also been applied to the microalgae harvesting process. In the last few decades, chitosan has emerged as a favorable flocculating agent in harvesting microalgae. Chitosan is becoming increasingly important as a natural biopolymer due to its unique combination of properties like biodegradability, biocompatibility, renewability, bioactivity, and ecological acceptability, in addition to attractive physical and mechanical properties [23]. It also has variety of current and potential applications in wastewater treatment [24], biomedical engineering [25], food processing [26], and so forth. In particular, chitosan has also been examined to formulate nanoparticles to facilitate targeting drug to specified organ [27].

\section{General Aspects of Chitosan}

Chitosan, poly- $\beta$ (1-4)-2-amino-2-deoxy-d-glucopyranose, is a cationic polyelectrolyte obtained by deacetylation of chitin. Chitin and chitosan are both aminoglucopyrans composed of N-acetylglucosamine (GlcNAc) and glucosamine (GlcN) residues. The chemical structures of chitin and chitosan are shown in Figure 1 [28]. Acetamide group of chitin can be converted into amino group to give chitosan, when the degree of deacetylation of chitin reaches about $50 \%$ (depending on the origin of the polymer). Chitosan is also polyelectrolyte which has several million Daltons. The average molecular weight of commercially available chitosan ranges between 3800 and 20,000 Daltons and is $66 \%$ to $95 \%$ deacetylated. The chitosan toxicity tests showed that the toxicity was negligible [29]. Because chitosan can be produced in various forms such as powder, paste, film, and fiber, it is more widely applied in industry than chitin [30].

Due to the presence of three different polar functional groups $\left(-\mathrm{OH},-\mathrm{NH}_{2}\right.$, and $\left.\mathrm{C}-\mathrm{O}-\mathrm{C}\right)$, chitosan has high water capacity [28]. Chitosan has the special quality of gelling upon contact with anions, forming beads under very mild conditions [31]. And the presence of amino groups makes chitosan a cationic polyelectrolyte $(\mathrm{pKa}=6.5)$, one of the few found in nature [32]. Ordinary chitosan is insoluble in water at near neutral $\mathrm{pH}$ and most common organic 


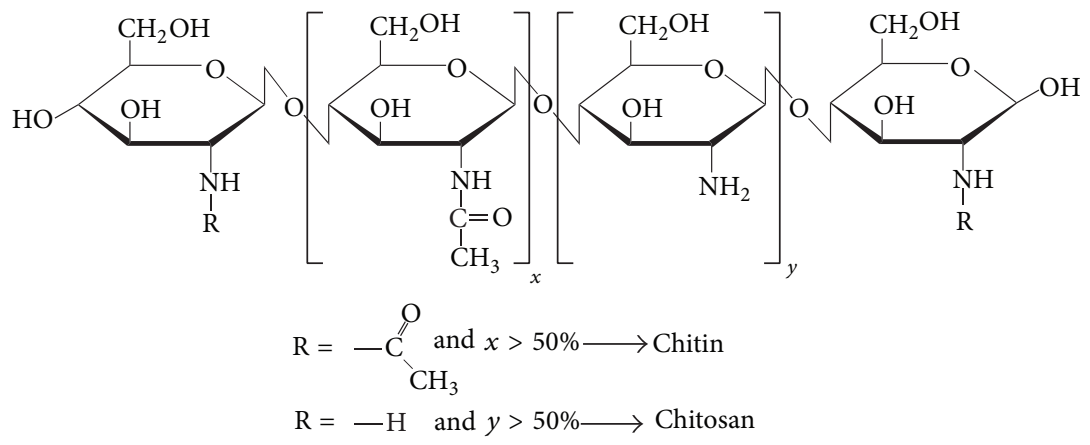

FIGURE 1: Structures of chitin and chitosan [28].

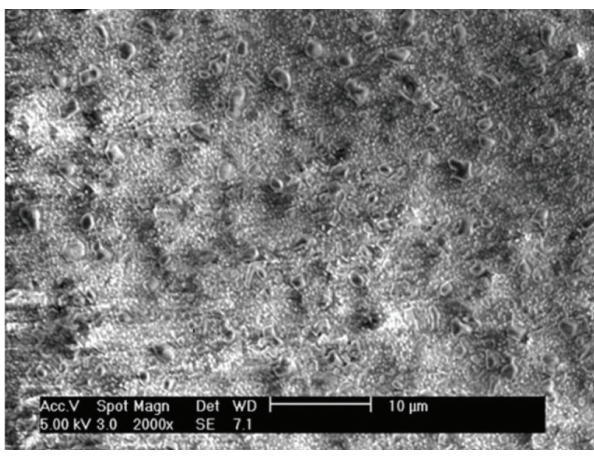

(a)

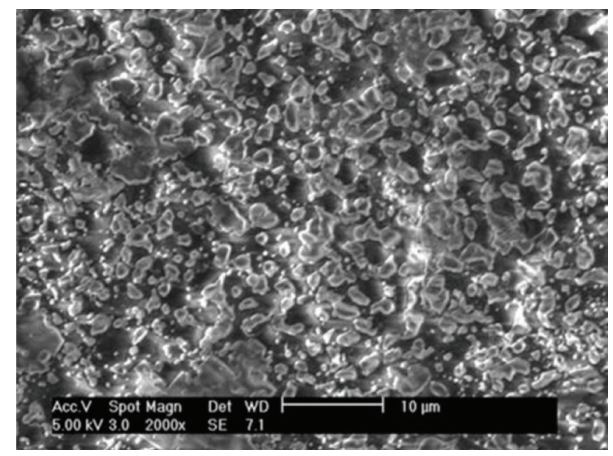

(b)

FIGURE 2: (a) SEM of C. vulgaris before harvesting. (b) SEM of C. vulgaris after harvesting [38].

solvents (e.g., DMSO, DMF, NMP, organic alcohols, and pyridine), which is attributed to extensive intramolecular and intermolecular hydrogen bonding between the chains and sheets, respectively [33]. Chitosan can be soluble in some diluted organic acids (such as acetic, formic, and lactic acids) and some inorganic acid. Although the distribution of acetyl groups along the chain may modify solubility [34], the solubilization is mainly due to the protonation of $\mathrm{NH}_{2}$ groups on the $\mathrm{C}_{2}$ position of the $\beta$-glucosamine unit.

\section{Chitosan Applied in Harvesting Microalgae}

Chitosan not only has been proved highly effective for water treatment and environmental protection, but also shows interesting properties in removing both freshwater algae and marine algae.

The most likely mechanisms involved in this coagulation are adsorption and charge neutralization. Chitosan has a net positive charge because of the high charge density of the chitosan. As the overall charge of microalgae cells is negative, the positively charged chitosan is strongly adsorbed on microalgae cells, which results in most of the charged groups being close to the surface of the cells [35] and effectively destabilize the microalgae [36]. Chitosan first neutralizes charges on the microalgae cells, weakens the electrostatic repulsion between the microalgae cells, and then reduces the interparticle repulsion. Such effect is called charge neutralization [37].
Some authors report chitosan as an effective algal flocculant. Figure 2 shows the scan electron microscope (SEM) of Chlorella vulgaris before and after flocculation by chitosan. After flocculation, C. vulgaris algae were surrounded by chitosan, and the surface became fibrillar. This change of surface was observably caused by chitosan, which possesses heterogeneous surface structure [38].

Using life cycle assessment (LCA), Beach compared the chitosan method to centrifugation and filtration/chamber press methods [39]. Figure 3 showed the system used as a basis for the comparison, where the cultivation and downstream were assumed to be equivalent among all methods. LCA showed that flocculation by chitosan for harvesting $N$. oleoabundans is the least energy intensive and had the best profile across all other categories of environmental impacts.

4.1. Effect of Chitosan Dosage on Flocculation Efficiency. In general, chitosan can effectively flocculate algal species at $5 \mathrm{mg} / \mathrm{L}$ to $200 \mathrm{mg} / \mathrm{L}$. Divakaran and Sivasankara Pillai [40] reported that chitosan successfully removed $90 \%$ of turbidity with chitosan concentration of $5 \mathrm{mg} / \mathrm{L}$. Ahmad et al. [41] reported a $99.0 \pm 0.4 \%$ of Chlorella sp. removal at $10 \mathrm{ppm}$ of chitosan. In order to obtain 95-100\% flocculation efficiency, chitosan concentration was about $20 \mathrm{mg} / \mathrm{L}$ for Chlorella and $2 \mathrm{mg} / \mathrm{L}$ for $S$. Costatum [16]. Chitosan is required in low dosage in freshwater but its flocculating power is reduced in salt water. 


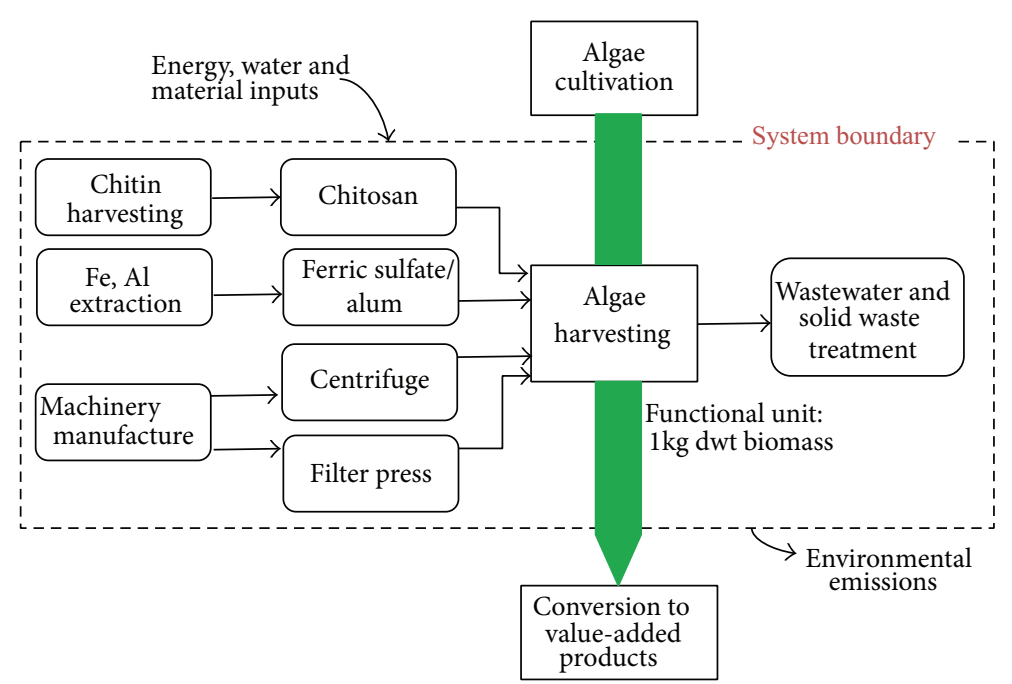

Figure 3: Overview of the system used as a basis for the comparison [39].

Chitosan's ability to remove microalgae effectively at low dosage is partly caused by its' properties. Chitosan not only acts as an adsorbent, but also spontaneously coagulates to agglomerate the microalgae cells. However, when using overdose of chitosan, the percentage of microalgae cells removed declined sharply, which may be caused by charge neutralization and bridging phenomena. During the flocculation, cationic charge of chitosan attracts the negatively charged microalgae, reducing the electrostatic repulsion among microalgal cells and then forming the flocs. Excess amino group led to restabilization of the microalgae and decreasing of separation efficiency [38].

4.2. Effect of $p H$ on Flocculation Efficiency. The importance of $\mathrm{pH}$ on flocculation of microalgae was investigated by many researchers [41-44]. The influence of $\mathrm{pH}$ on chitosan's molecular structure can be due to differences in the protonation of the biopolymer amine groups and variations in the conformation of the macromolecule chain and in the structure of the flocs [37]. In alkaline solutions, the positive charge gradually disappeared and chitosan is able to produce large and dense flocks. When the $\mathrm{pH}$ increases to neutralization point, the algal cells have the highest negative charge, and the flocculation efficiency is enhanced as the electrostatic interaction between the algal cells and chitosan, whereas, in acidic solutions, chitosan becomes a more extended chain and therefore produces smaller looser flocs [20]. In the study of Divakaran and Sivasankara Pillai [40], maximum clarification was obtained at $\mathrm{pH} 7$ for the freshwater species. Cheng et al. reported that a higher $\mathrm{pH}$ at 8.5 was optimal for Chlorella sorokiniana [42]. In the study of an even higher $\mathrm{pH}$ at $9.9,90 \%$ of Phaeodactylum tricornutum was harvested with 20 ppm chitosan [18].

Morales suggested that chitosan activity and flocculation efficiency were increased as the viscosity and the mean surface charge of algal cells were decreased when $\mathrm{pH}$ was below 7 [16]. While Xu et al. reported that when the working
$\mathrm{pH}$ was at 6 or 5 , half the amount of chitosan was needed to induce effective flocculation compared to $\mathrm{pH} 7$ [43].

These differences in response to $\mathrm{pH}$ can be explained by difference in culture media, growth conditions, and unique strain properties, such as cell morphology, extracellular organic matter, and cell surface charge [44].

4.3. Effect of Algae Species on Flocculation Efficiency. The flocculation efficiency of algal suspension is different from one algal species to another. Chlorella vulgaris reached $99.7 \%$ removal rate at $200 \mathrm{mg} / \mathrm{L}$ chitosan [45]. While $150 \mathrm{mg} / \mathrm{L}$ of chitosan was required for optimal flocculation of Chaetoceros muelleri [46]. For Skeletonema costatum $2 \mathrm{mg} / \mathrm{L}$ of chitosan was needed when $95 \%$ flocculation efficiency was obtained. Optimal flocculation of some species was list in Table 1.

\section{Chitosan Modified Flocculants and Their Flocculation Efficiency}

Chitosan exhibits limitations in its reactivity and process ability. For a breakthrough in utilization of chitosan in flocculation of microalgae, chitosan modification to introduce a variety of functional groups will be a key point. Chitosan can be modified by chemical or physical processes to improve the mechanical and chemical properties. The efficiency of adsorption depends on physicochemical properties, mainly surface area, porosity, and particle size of adsorbents. As such procedure would not change the fundamental skeleton of polymers, chitosan would keep its original physicochemical and biochemical properties and finally would bring new or improved properties [47]. A great number of chitosan derivatives have been obtained by grafting new functional groups on the chitosan backbone to increase adsorption capacity. The new functional groups are incorporated to increase the density of sorption sites, to change the $\mathrm{pH}$ range for sorption, and to change the sorption sites in order to increase sorption. The chemical modification affords a wide range of derivatives 


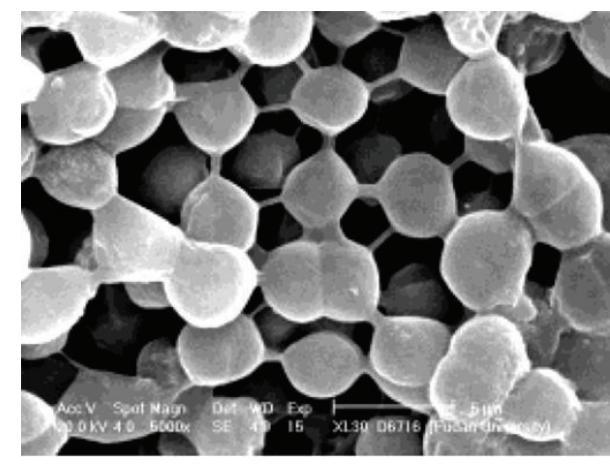

(a)

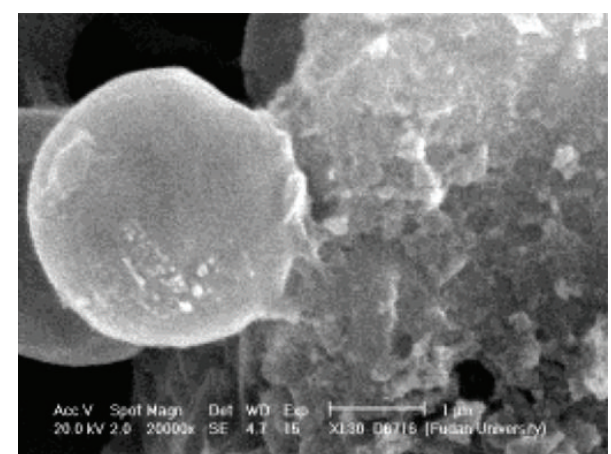

(b)

FIGURE 4: SEM images of algae treated with chitosan modified adsorbent [53].

TABLE 1: Optimal flocculation of some microalgae.

\begin{tabular}{|c|c|c|c|c|}
\hline Species & Chitosan dosage & Parameters & Flocculation efficiency & References \\
\hline Chaetoceros calcitrans & $80 \mathrm{mg} / \mathrm{L}$ & $\mathrm{pH} 8.0$ & $80 \%$ & [46] \\
\hline Chaetoceros muelleri & $150 \mathrm{mg} / \mathrm{L}$ & $\mathrm{pH} 8.0$ & $95 \%$ & {$[46]$} \\
\hline Chlorella & $5.0 \mathrm{mg} / \mathrm{L}$ & $\mathrm{pH} 7.0$ & $90 \%$ & [63] \\
\hline Chlorella consortium & $25 \mathrm{mg} / \mathrm{L}$ & $\begin{array}{l}\text { Stirring for } 1 \mathrm{~min} \text {, settling for } \\
10 \mathrm{~min}\end{array}$ & $58 \pm 8$ & {$[10]$} \\
\hline Chlorella sorokiniana & $10 \mathrm{mg} /$ gram algal dry weight & pH 6 & $99 \%$ & {$[43]$} \\
\hline Chlorella sorokiniana & $25 \mathrm{mg} / \mathrm{L}$ & $\begin{array}{l}\text { Stirring for } 1 \mathrm{~min} \text {, settling for } \\
10 \mathrm{~min}\end{array}$ & $30 \pm 11$ & {$[10]$} \\
\hline Chlorella sp. & $10 \mathrm{ppm}$ & $\begin{array}{l}\text { Mixing for } 20 \mathrm{~min} \text {, mixing at } \\
150 \mathrm{ppm} \text {, and sedimenting for } \\
20 \mathrm{~min}\end{array}$ & $99.0 \pm 0.4 \%$ & {$[41]$} \\
\hline Chlorella vulgaris & $200 \mathrm{mg} / \mathrm{L}$ & In a logarithmic growth phase & $99.7 \%$ & {$[45]$} \\
\hline Chlorella vulgaris & $30 \mathrm{mg} / \mathrm{L}$ & $\begin{array}{l}\mathrm{pH} 8.7 \text {, } \\
300 \mathrm{rpm} \text {, and settling for } 10 \mathrm{~min} \text {. }\end{array}$ & $92 \%$ & {$[38]$} \\
\hline Chlorella vulgaris and Microcystis sp. & $214 \mathrm{mg} / \mathrm{L}$ & $\begin{array}{l}\text { Fish-processing wastewater, } \\
\text { agitation speed of } 131 \mathrm{rpm}\end{array}$ & $91.9 \%$ & {$[64]$} \\
\hline Chlorococcum sp. & $25 \mathrm{mg} / \mathrm{L}$ & $\begin{array}{l}\text { Stirring for } 1 \mathrm{~min} \text {, settling for } \\
10 \mathrm{~min}\end{array}$ & $38 \pm 1$ & {$[10]$} \\
\hline Nannochloropsis sp. & $100 \mathrm{mg} / \mathrm{L}$ & pH 9.0 & $92 \%$ & {$[62]$} \\
\hline Neochloris oleoabundans & $100 \mathrm{mg} / \mathrm{L}$ & $\begin{array}{l}\text { Mixing time for } 10 \mathrm{~min} \text {, mixing } \\
\text { rate of } 350 \mathrm{rpm}\end{array}$ & $95 \%$ & {$[39]$} \\
\hline Pavlova lutheri & $80 \mathrm{mg} / \mathrm{L}$ & pH 8.0 & $80 \%$ & {$[46]$} \\
\hline Phaeodactylum tricornutum & $20 \mathrm{mg} / \mathrm{L}$ & $\begin{array}{l}\text { pH } 9.9 \\
\text { Settling time of } 10 \mathrm{~min}\end{array}$ & $92 \%$ & {$[18]$} \\
\hline Scenedesmus costatum & $2 \mathrm{mg} / \mathrm{L}$ & pH 7 & $95-100 \%$ & {$[16]$} \\
\hline Scenedesmus obliquus & $25 \mathrm{mg} / \mathrm{L}$ & $\begin{array}{l}\text { Stirring for } 1 \mathrm{~min} \text {, settling for } \\
10 \mathrm{~min}\end{array}$ & $20 \pm 15$ & {$[10]$} \\
\hline Scenedesmus quadricauda & $10 \mathrm{mg} / \mathrm{L}$ & $\begin{array}{l}\mathrm{pH} 8.0 \text {; SDS was used as the } \\
\text { collector }\end{array}$ & $90 \%$ & {$[65]$} \\
\hline Skeletonema costatum & $80 \mathrm{mg} / \mathrm{L}$ & pH 8.0 & $70 \%$ & {$[46]$} \\
\hline Synechocystis & $15 \mathrm{mg} / \mathrm{L}$ & $\mathrm{pH} 7.0$ & $>90 \%$ & {$[63]$} \\
\hline Tahitian Isochrysis & $40 \mathrm{mg} / \mathrm{L}$ & $\mathrm{pH} 8.0$ & $90 \%$ & {$[46]$} \\
\hline Tetraselmis chui & $40 \mathrm{mg} / \mathrm{L}$ & $\mathrm{pH} 8.0$ & $80 \%$ & {$[46]$} \\
\hline Thalassiosira pseudonana & $40 \mathrm{mg} / \mathrm{L}$ & $\mathrm{pH} 8.0$ & $90 \%$ & {$[46]$} \\
\hline
\end{tabular}




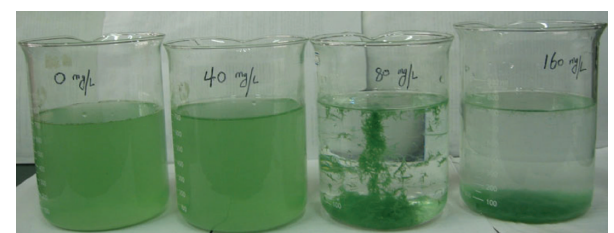

FIGURE 5: Flocculation character of CMK and M. aeruginosa NIES843 at different CMK loading levels [54].

with modified properties for specific use and applications in diversified areas mainly of pharmaceutical, biomedical, and biotechnological fields [32]. Such modification can also be applied to harvesting microalgae.

5.1. Chitosan Modified Soils. Chitosan modified by soil particles (including the silica sand and local soil) showed highly effective in flocculating algae cells [48-52]. Pan and coworkers found that local soil particles including sand were critical for speeding up the kinetic processes of flocculation and sedimentation of algal flocs. The polymeric netting and bridging function of chitosan were the key mechanisms that allowed local soil particles to quickly flocculate algal biomass. Chitosan modified adsorbent has the functions of both flocculation and adsorption. Figure 4(a) shows the function of bridging, while Figure 4(b) illustrates the function of adsorption [53]. The chitosan made a "net" that captured the algae cells and other particles, and the soils provided the ballast or mass to carry the aggregates to the bottom. Chitosan was also important in inhibiting the escape of cells from the flocs. Chitosan and polyaluminium chloride used together as modifiers make it possible to use local beach sand for harvesting microalgae in seawater [50].

Shao et al. studied the physiological responses of Microcystis aeruginosa under the stress of chitosan modified kaolinite (CMK). When flocculated with CMK, Chl a, carotenoids, phycocyanin, and allophycocyanin were much lower than the control. The results indicated that high level of CMK could cause cellular membranes damage and then the intracellular substances leakage and finally could cause the death of $M$. aeruginosa NIES-843 cell. Figure 5 showed that the strain can be effectively flocculated by CMK at 80 and $160 \mathrm{mg} / \mathrm{L}$. However, the Microcystis cultures turned to be bluish at that time, which indicated the leakage of phycobilins [54].

\subsection{Aluminum Chloride and Aluminium Sulphate Modified Chitosan Used as Flocculants}

5.2.1. Aluminum Chloride Modified Chitosan. Chitosan could enhance the flocculation performance of polyaluminium chloride (PAC), when the high algae-laden water was treated by coagulation/flocculation/dissolved air flotation (C/F/DAF) [55]. The removal rate of algae cells was increased apparently compared with adding PAC alone. The structure and strength of flocs were improved when less than $1.0 \mathrm{mg} / \mathrm{L}$ chitosan was added, which significantly reduced the residual aluminum concentration.
Zhang et al. reported a composite coagulant (PACl-CTS), which was made of polyaluminum chloride and chitosan. When $21.0 \mathrm{mg} / \mathrm{L}$ of the coagulant is added, $98.15 \%$ turbidity, $67.78 \%$ COD, and $84.05 \%$ TP can be removed. This coagulant can be applied in the pretreatment of blue algae biogas slurry [56]. Figure 6 showed the SEM of PACl-CTS. PACl with certain crystal structure was embedded in chitosan, which enabled the composite coagulant to possess much more positive charge. When the PACl-CTS was added to the algal water, it can decrease the negative charge on the surface of microalgae and enhance the flocculation by polymer bridging.

5.2.2. Aluminium Sulphate Modified Chitosan. Wang et al. used aluminium sulphate and chitosan as coagulants to treat the high algae-laden water. The compound action of aluminium sulphate and chitosan can reduce dosage of aluminum salt coagulant for meeting the treatment requirements, which in turn reduces the residual aluminium in treated water. Moreover, with the coagulation aid of chitosan, the algae flocs were larger and more compact and had a faster settling velocity [57].

5.3. Fly Ash Modified Chitosan. The performance of activated fly ash modified chitosan (FA-MC) as a flocculant to remove Microcystis aeruginosa was reported by Qiao et al. [58]. $90 \%$ of algae can be removed at the dosage of $0.25 \mathrm{mg} / \mathrm{L}$ chitosan within $1 \mathrm{~h}$ or at the dosage of $0.35 \mathrm{mg} / \mathrm{L}$ chitosan within $40 \mathrm{~min}$. The authors found that the algal extracellular organic matter had a priority to consumption of flocculant in initial period of flocculation. In the late stage of flocculation, extracellular organic matter can decrease the adsorption bridging and entrapping-weeping functions of fly ash modified chitosan.

5.4. Magnetic Chitosan. Ferroferric oxide modified with chitosan was used to remove algal in freshwater [59]. This magnetic polymer could remove over $99 \%$ algal cells, which is much more effective when comparing with chitosan or $\mathrm{Fe}_{3} \mathrm{O}_{4}$ alone. The author found that the high algal removal efficiency of magnetic polymer is due to the cooperation between chitosan and $\mathrm{Fe}_{3} \mathrm{O}_{4}$ particles. Chitosan can enhance the function of netting and bridging in flocculating algal cells, while the $\mathrm{Fe}_{3} \mathrm{O}_{4}$ could separate the flocculated algal cells from water by its high magnetic response in the presence of magnetic field. Figure 7 showed the SEM of algal cells that was captured by magnetic polymer. The network bridge of chitosan and the magnetic $\mathrm{Fe}_{3} \mathrm{O}_{4}$ agglomerated the cells. After flocculation, the algae cells were still kept in original shape, which indicated that the flocculant did not destroy the cells.

This technique has been successfully applied to pilot experiments in Chaohu Lake, China.

5.5. Nanochitosan. Nanoscaled chitosan particles are prepared by some researchers. Such chitosan-coated nanoparticles have overcome the limitation of microscaled particles 

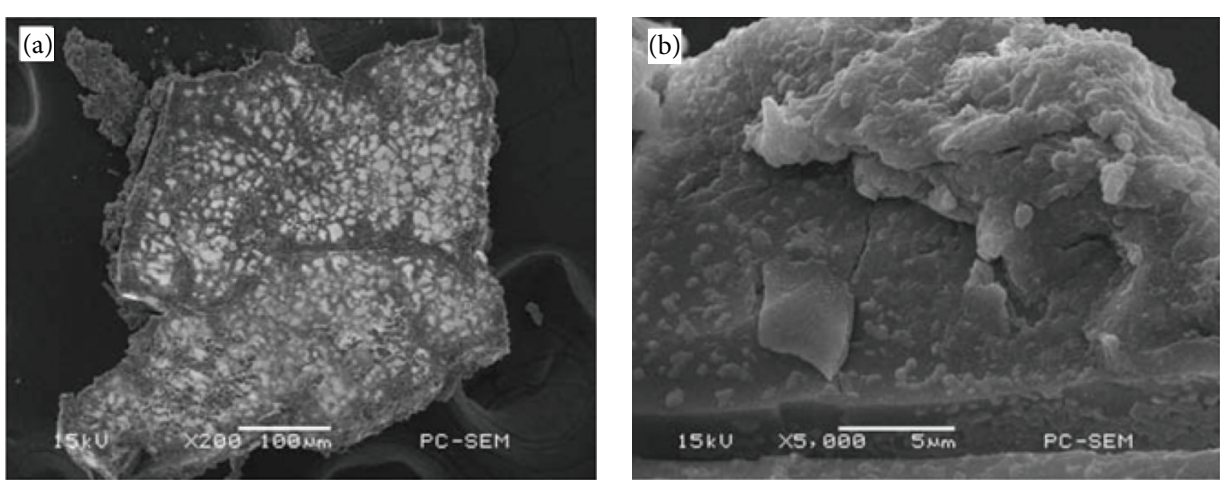

Figure 6: SEM of PACl-CTS [56].

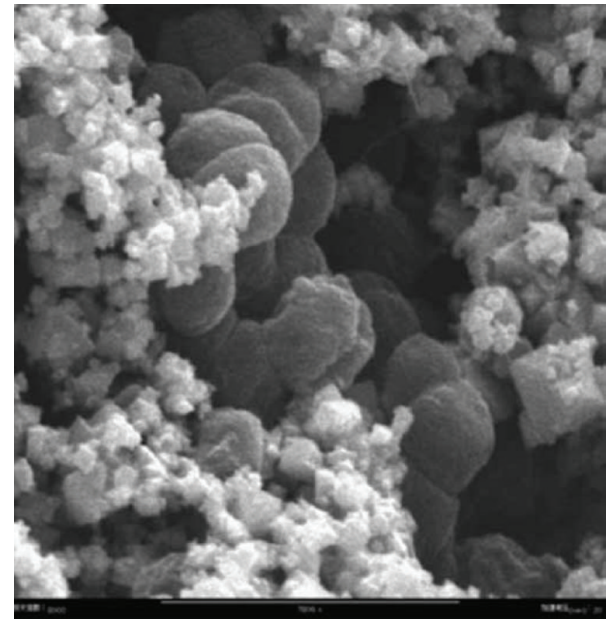

FIGURE 7: SEM images of the floccules of magnetic polymer algal cells $(\times 8,000)$ [59].

by providing larger surface area. Owning to high adsorption capacity and stability, these particles can be used as adsorbents for food dyes adsorption [60], protein [61], and microalgae.

Farid et al. prepared chitosan nanopolymer using ionic gelation method, which added sodium tripolyphosphate to chitosan solution [62]. The average of particle size was $13.7 \mathrm{~nm}$.

When nanochitosan was used as flocculant agent, the dosage of flocculant consumption decreased to $60 \mathrm{mg} / \mathrm{L}$, while the optimum chitosan dosage was $100 \mathrm{mg} / \mathrm{L}$ for harvesting. The removal efficiency was about $98 \%$, which increased by $9 \%$ when nanochitosan instead of chitosan was used. The author figured out that the nanochitosan had high harvesting rate because its particle had ions cross-linked with sodium tripolyphosphate. When chitosan is dissolved in water at acidic $\mathrm{pH}$, it gives both hydrated amino group and $-\mathrm{NH}_{3}{ }^{+}$ions. The sodium tripolyphosphate (STPP, $\mathrm{Na}_{5} \mathrm{P}_{3} \mathrm{O}_{10}$ ) presents both hydroxyl and phosphoric ions in water. These phosphoric ions of STPP can interact with $-\mathrm{NH}_{3}{ }^{+}$ions of chitosan, lead to crosslinking between chitosan and STPP, and result in big network of polymers, which adsorb microalgae and create a greater degree of bridging. In addition, the nanosize particles increase the adsorption ability and contact surfaces.

The author also analyzed the cost of harvesting process. For production of $1 \mathrm{~kg}$ of dry biomass, harvesting process would cost about $\$ 0.0246$, which showed the feasibility of using nanochitosan as flocculation agent.

\section{Conclusions}

Flocculation using chitosan is becoming a promising alternative to replace conventional flocculants in removing/harvesting microalgae. Although chitosan itself can flocculate algae, the use of some modification process may improve the properties of chitosan. Arguments on which flocculant is better in harvesting microalgae are still going on as each of the flocculants has its own advantages and disadvantages. Due to the different experimental conditions, such as $\mathrm{pH}$, microalgae species, and ionic strength, it is different to compare the lowcost flocculants. Meanwhile, more studies should transfer to industrial scale.

\section{Conflict of Interests}

The authors declare that there is no conflict of interests.

\section{Acknowledgments}

Financial support from the National Natural Science Foundation of China (Grant nos. 51108310 and 51036006) and support from the Project for Developing Marine Economy by Science and Technology in Tianjin (KX2010-0005) are highly appreciated.

\section{References}

[1] C.-Y. Chen, K.-L. Yeh, R. Aisyah, D.-J. Lee, and J.-S. Chang, "Cultivation, photobioreactor design and harvesting of microalgae for biodiesel production: a critical review," Bioresource Technology, vol. 102, no. 1, pp. 71-81, 2011.

[2] G. Huang, F. Chen, D. Wei, X. Zhang, and G. Chen, "Biodiesel production by microalgal biotechnology," Applied Energy, vol. 87, no. 1, pp. 38-46, 2010. 
[3] Y. Chisti, "Biodiesel from microalgae beats bioethanol," Trends in Biotechnology, vol. 26, no. 3, pp. 126-131, 2008.

[4] I. Rawat, R. R. Kumar, T. Mutanda et al., "Biodiesel from microalgae: a critical evaluation from laboratory to large scale production," Applied Energy, vol. 103, pp. 444-467, 2013.

[5] T. M. Mata, A. A. Martins, and N. S. Caetano, "Microalgae for biodiesel production and other applications: a review," Renewable and Sustainable Energy Reviews, vol. 14, no. 1, pp. 217232, 2010.

[6] Y. Chisti, "Biodiesel from microalgae," Biotechnology Advances, vol. 25, no. 3, pp. 294-306, 2007.

[7] S. A. Scott, M. P. Davey, J. S. Dennis et al., "Biodiesel from algae: challenges and prospects," Current Opinion in Biotechnology, vol. 21, no. 3, pp. 277-286, 2010.

[8] H. M. Amaro, A. C. Guedes, and F. X. Malcata, "Advances and perspectives in using microalgae to produce biodiesel," Applied Energy, vol. 88, no. 10, pp. 3402-3410, 2011.

[9] I. Rawat, R. R. Kumar, T. Mutanda et al., "Biodiesel from microalgae: a critical evaluation from laboratory to large scale production," Applied Energy, vol. 103, pp. 444-467, 2013.

[10] I. de Godos, H. O. Guzman, R. Soto et al., "Coagulation/ flocculation-based removal of algal-bacterial biomass from piggery wastewater treatment," Bioresource Technology, vol. 102, no. 2, pp. 923-927, 2011.

[11] G. E. Molina, E.-H. Belarbi, F. G. Acién Fernández, A. Robles Medina, and Y. Chisti, "Recovery of microalgal biomass and metabolites: process options and economics," Biotechnology Advances, vol. 20, no. 7-8, pp. 491-515, 2003.

[12] N. Uduman, Y. Qi, M. K. Danquah, G. M. Forde, and A. Hoadley, "Dewatering of microalgal cultures: a major bottleneck to algae-based fuels," Journal of Renewable and Sustainable Energy, vol. 2, no. 1, Article ID 012701, 2010.

[13] D. Vandamme, I. Foubert, B. Meesschaert, and K. Muylaert, "Flocculation of microalgae using cationic starch," Journal of Applied Phycology, vol. 22, no. 4, pp. 525-530, 2010.

[14] N.-H. Norsker, M. J. Barbosa, M. H. Vermuë, and R. H. Wijffels, "Microalgal production-a close look at the economics," Biotechnology Advances, vol. 29, no. 1, pp. 24-27, 2011.

[15] E. M. Grima, E. H. Belarbia, F. G. A. Fernándeza et al., "Recovery of microalgal biomass and metabolites: process options and economics," Biotechnology Advances, vol. 20, no. 7-8, pp. 491515, 2003.

[16] J. Morales, J. de la Noüe, and G. Picard, "Harvesting marine microalgae species by chitosan flocculation," Aquacultural Engineering, vol. 4, no. 4, pp. 257-270, 1985.

[17] L. Brennan and P. Owende, "Biofuels from microalgae-a review of technologies for production, processing, and extractions of biofuels and co-products," Renewable and Sustainable Energy Reviews, vol. 14, no. 2, pp. 557-577, 2010.

[18] S. Şirin, R. Trobajo, C. Ibanez, and J. Salvadó, "Harvesting the microalgae Phaeodactylum tricornutum with polyaluminum chloride, aluminium sulphate, chitosan and alkalinity-induced flocculation," Journal of Applied Phycology, vol. 24, no. 5, pp. 1067-1080, 2011.

[19] P. M. Schenk, S. R. Thomas-Hall, E. Stephens et al., "Second generation biofuels: high-efficiency microalgae for biodiesel production," BioEnergy Research, vol. 1, pp. 20-43, 2008.

[20] C. Huang, S. Chen, and J. Ruhsing Pan, "Optimal condition for modification of chitosan: a biopolymer for coagulation of colloidal particles," Water Research, vol. 34, no. 3, pp. 1057-1062, 2000 .
[21] T. Okuda, A. U. Baes, W. Nishijima, and M. Okada, "Improvement of extraction method of coagulation active components from Moringa oleifera seed," Water Research, vol. 33, no. 15, pp. 3373-3378, 1999.

[22] M. Özacar and I. A. Şengil, "Evaluation of tannin biopolymer as a coagulant aid for coagulation of colloidal particles," Colloids and Surfaces A, vol. 229, no. 1-3, pp. 85-96, 2003.

[23] A. J. Varma, S. V. Deshpande, and J. F. Kennedy, "Metal complexation by chitosan and its derivatives: a review," Carbohydrate Polymers, vol. 55, no. 1, pp. 77-93, 2004.

[24] C. Y. Hu, S. L. Lo, Chang, C. L et al., "Treatment of highly turbid water using chitosan and aluminum salts," Separation and Purification Technology, vol. 104, pp. 322-326, 2013.

[25] J. M. Silva, N. Georgi, R. Costa et al., "Nanostructured 3D constructs based on chitosan and Chondroitin Sulphate multilayers for cartilage tissue engineering," Plos ONE, vol. 8, no. 2, Article ID e55451, 2013.

[26] F. Shahidi, J. K. V. Arachchi, and Y.-J. Jeon, "Food applications of chitin and chitosans," Trends in Food Science and Technology, vol. 10, no. 2, pp. 37-51, 1999.

[27] K. Ganguly, T. M. Aminabhavi, and A. R. Kulkarni, "Colon targeting of 5-fluorouracil using polyethylene glycol cross-linked chitosan microspheres enteric coated with cellulose acetate phthalate," Industrial and Engineering Chemistry Research, vol. 50, no. 21, pp. 11797-11807, 2011.

[28] J. Ma and Y. Sahai, "Chitosan biopolymer for fuel cell applications," Carbohydrate Polymers, vol. 92, no. 2, pp. 955-975, 2013.

[29] L. Illum, "Chitosan and its use as a pharmaceutical excipient," Pharmaceutical Research, vol. 15, no. 9, pp. 1326-1331, 1998.

[30] S. A. Agnihotri, N. N. Mallikarjuna, and T. M. Aminabhavi, "Recent advances on chitosan-based micro- and nanoparticles in drug delivery," Journal of Controlled Release, vol. 100, no. 1, pp. 5-28, 2004.

[31] S. C. Angadi, L. S. Manjeshwar, and T. M. Aminabhavi, "Stearic acid-coated chitosan-based interpenetrating polymer network microspheres: controlled release characteristics," Industrial and Engineering Chemistry Research, vol. 50, no. 8, pp. 4504-4514, 2011.

[32] P. Miretzky and A. F. Cirelli, "Fluoride removal from water by chitosan derivatives and composites: a review," Journal of Fluorine Chemistry, vol. 132, no. 4, pp. 231-240, 2011.

[33] T. Yui, K. Imada, K. Okuyama, Y. Obata, K. Suzuki, and K. Ogawa, "Molecular and crystal structure of the anhydrous form of chitosan," Macromolecules, vol. 27, no. 26, pp. 7601-7605, 1994.

[34] M. Rinaudo, "Characterization and properties of some polysaccharides used as biomaterials," Macromolecular Symposia, vol. 245-246, no. 1, pp. 549-557, 2006.

[35] D. M. Ruthven, Encyclopedia of Separation Technology, vol. 1 of A Kirk-Othmer Encyclopedia, John Wiley \& Sons, New York, NY, USA, 1997.

[36] X. Wu, X. Ge, D. Wang, and H. Tang, "Distinct coagulation mechanism and model between alum and high Al13-PACl," Colloids and Surfaces A, vol. 305, no. 1-3, pp. 89-96, 2007.

[37] F. Renault, B. Sancey, P.-M. Badot, and G. Crini, "Chitosan for coagulation/flocculation processes-an eco-friendly approach," European Polymer Journal, vol. 45, no. 5, pp. 1337-1348, 2009.

[38] N. Rashid, M. S. Rehman, and J. I. Han, "Use of chitosan acid solutions to improve separation efficiency for harvesting of the microalga Chlorella vulgaris," Chemical Engineering Journal, vol. 226, pp. 238-242, 2013. 
[39] E. S. Beach, M. J. Eckelman, Z. Cui et al., "Preferential technological and life cycle environmental performance of chitosan flocculation for harvesting of the green algae Neochloris oleoabundans," Bioresource Technology, vol. 121, pp. 445-449, 2012.

[40] R. Divakaran and V. N. Sivasankara Pillai, "Flocculation of river silt using chitosan," Water Research, vol. 36, no. 9, pp. 2414-2418, 2002.

[41] A. L. Ahmad, N. H. Mat Yasin, C. J. C. Derek, and J. K. Lim, "Optimization of microalgae coagulation process using chitosan," Chemical Engineering Journal, vol. 173, no. 3, pp. 879$882,2011$.

[42] Y.-S. Cheng, Y. Zheng, J. M. Labavitch, and J. S. Vandergheynst, "The impact of cell wall carbohydrate composition on the chitosan flocculation of Chlorella," Process Biochemistry, vol. 46, no. 10, pp. 1927-1933, 2011.

[43] Y. N. Xu, S. Purton, and F. Baganz, "Chitosan flocculation to aid the harvesting of the microalga Chlorella sorokiniana," Bioresource Technology, vol. 129, pp. 296-301, 2013.

[44] R. Henderson, S. A. Parsons, and B. Jefferson, "The impact of algal properties and pre-oxidation on solid-liquid separation of algae," Water Research, vol. 42, no. 8-9, pp. 1827-1845, 2008.

[45] Y. R. Chang and D. J. Lee, "Coagulation-membrane filtration of Chlorella vulgaris at different growth phases," Drying Technology, vol. 30, no. 11-12, pp. 1317-1322, 2012.

[46] M. Heasman, J. Diemar, W. O’Connor, T. Sushames, and L. Foulkes, "Development of extended shelf-life microalgae concentrate diets harvested by centrifugation for bivalve molluscs-a summary," Aquaculture Research, vol. 31, no. 8-9, pp. 637-659, 2000.

[47] G. G. D’Ayala, M. Malinconico, and P. Laurienzo, "Marine derived polysaccharides for biomedical applications: chemical modification approaches," Molecules, vol. 13, no. 9, pp. 20692106, 2008.

[48] G. Pan, M.-M. Zhang, H. Chen, H. Zou, and H. Yan, "Removal of cyanobacterial blooms in Taihu Lake using local soils. I. Equilibrium and kinetic screening on the flocculation of Microcystis aeruginosa using commercially available clays and minerals," Environmental Pollution, vol. 141, no. 2, pp. 195-200, 2006.

[49] G. Pan, H. Zou, H. Chen, and X. Yuan, "Removal of harmful cyanobacterial blooms in Taihu Lake using local soils. III. Factors affecting the removal efficiency and an in situ field experiment using chitosan-modified local soils," Environmental Pollution, vol. 141, no. 2, pp. 206-212, 2006.

[50] G. Pan, J. Chen, and D. M. Anderson, "Modified local sands for the mitigation of harmful algal blooms," Harmful Algae, vol. 10, no. 4, pp. 381-387, 2011.

[51] G. Pan, L. Dai, L. Li et al., "Reducing the recruitment of sedimented algae and nutrient release into the overlying water using modified soil/sand flocculation-capping in eutrophic lakes," Environmental Science and Technology, vol. 46, no. 9, pp. 5077-5084, 2012.

[52] H. Zou, G. Pan, H. Chen, and X. Yuan, "Removal of cyanobacterial blooms in Taihu Lake using local soils. II. Effective removal of Microcystis aeruginosa using local soils and sediments modified by chitosan," Environmental Pollution, vol. 141, no. 2, pp. 201-205, 2006.

[53] X. Yang, C. Wu, Y. He, B. Zhang, and F. Li, "Removal effects and mechanisms of Microcystis aeruginosa by Chitosan-modified adsorbent," in Proceedings of the 2nd International Symposium on Aqua Science, Water Resource and Low Carbon Energy, vol. 1251 of AIP Conference Proceedings, pp. 125-128, December 2009.

[54] J. Shao, Z. Wang, Y. Liu et al., "Physiological responses of Microcystis aeruginosa NIES-843 (cyanobacterium) under the stress of chitosan modified kaolinite (CMK) loading," Ecotoxicology, vol. 21, no. 3, pp. 698-704, 2011.

[55] Y. H. Wang, S. G. Zhou, and Y. X. Yang, "Application of chitosan in removing algae by dissolved air flotation," in Advanced Materials Research, G. Li, Y. Huang, and C. Chen, Eds., vol. 347353, pp. 1911-1916, 2011.

[56] W. Zhang, P. Fan, Q. Li et al., "Synthsis of PACl-CTS composite coagulant and application in the pre-treatment of the blue algae biogas slurry," Environmental Chemistry, vol. 31, no. 7, pp. 10571062, 2012.

[57] Y. H. Wang, S. G. Zhuo, X. Y. Zhou et al., "Improvement of high algae-laden water treatment by coagulation aid of chitosan," in Advanced Materials Research, G. Li, Y. Huang, and C. Chen, Eds., vol. 250-253, pp. 3454-3459, 2011.

[58] J. Qiao, L. Dong, and Y. Hu, "Removal of harmful algal blooms using activated fly ash-modified chitosan," Fresenius Environmental Bulletin A, vol. 20, no. 3, pp. 764-772, 2011.

[59] D. Liu, F. Li, and B. Zhang, "Removal of algal blooms in freshwater using magnetic polymer," Water Science and Technology, vol. 59, no. 6, pp. 1085-1091, 2009.

[60] Z. K. Zhou, S. Q. Lin, T. L. Yue et al., "Adsorption of food dyes from aqueous solution by glutaraldehyde cross-linked magnetic chitosan nanoparticles," Journal of Food Engineering, vol. 126, pp. 133-141, 2014.

[61] J. S. Gonzalez, P. Nicolás, M. L. Ferreira et al., "Fabrication of ferrogels using different magnetic nanoparticles and their performance on protein adsorption," Polymer International, vol. 63, no. 2, pp. 258-265, 2014.

[62] M. S. Farid, A. Shariati, A. Badakhshan et al., "Using nanochitosan for harvesting microalga Nannochloropsis sp," Bioresource Technology, vol. 131, pp. 555-559, 2013.

[63] R. Divakaran and V. N. S. Pillai, "Flocculation of algae using chitosan," Journal of Applied Phycology, vol. 14, no. 5, pp. 419422, 2002.

[64] B. Riaño, B. Molinuevo, and M. C. García-González, "Optimization of chitosan flocculation for microalgal-bacteria biomass harvesting via response surface methodology," Ecological Engineering, vol. 38, no. 1, pp. 110-113, 2012.

[65] Y. M. Chen, J. C. Liu, and Y.-H. Ju, "Flotation removal of algae from water," Colloids and Surfaces B: Biointerfaces, vol. 12, no. 1, pp. 49-55, 1998. 

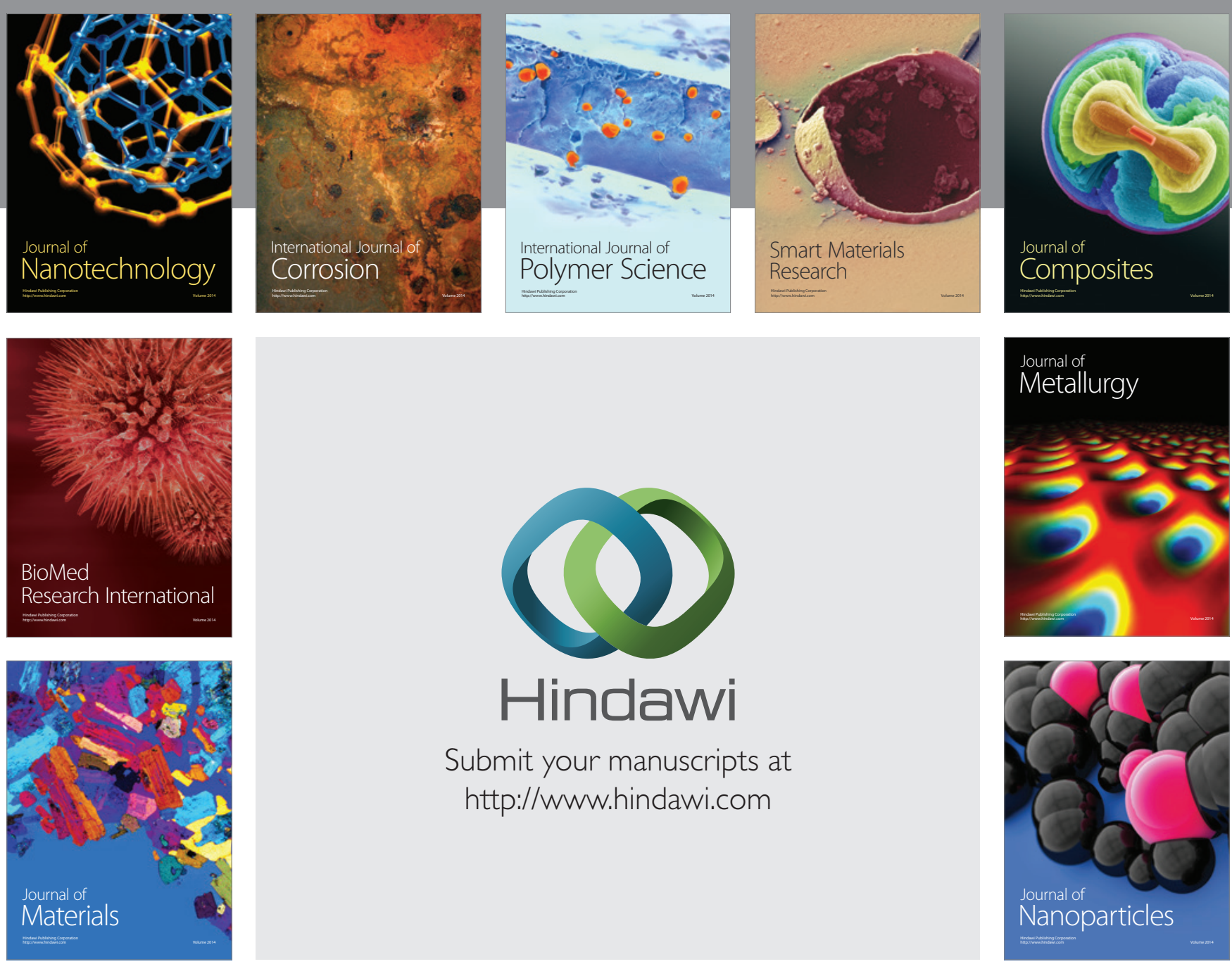

Submit your manuscripts at http://www.hindawi.com
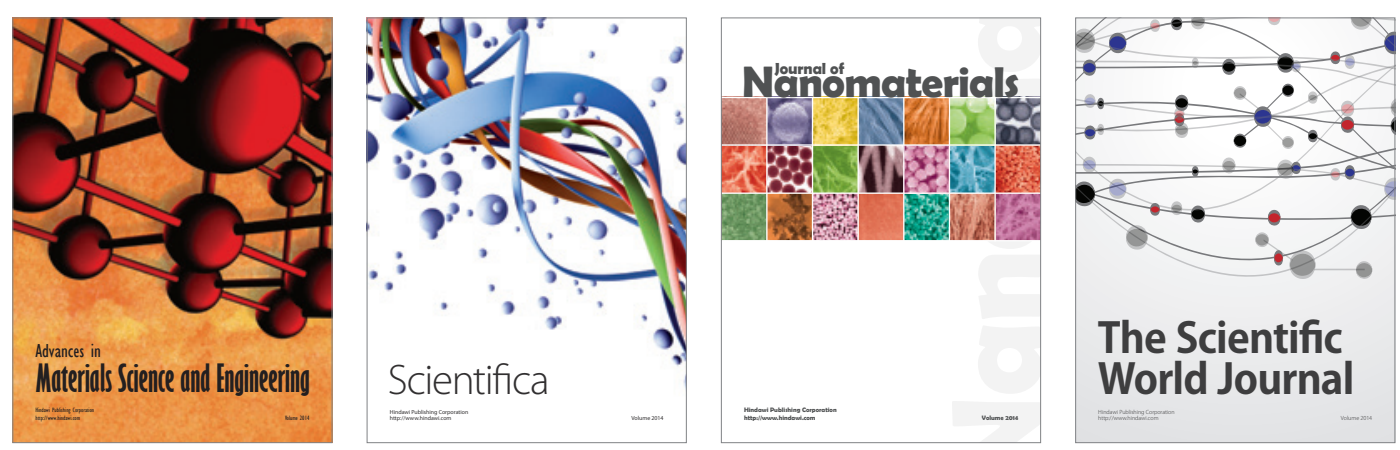

\section{The Scientific World Journal}
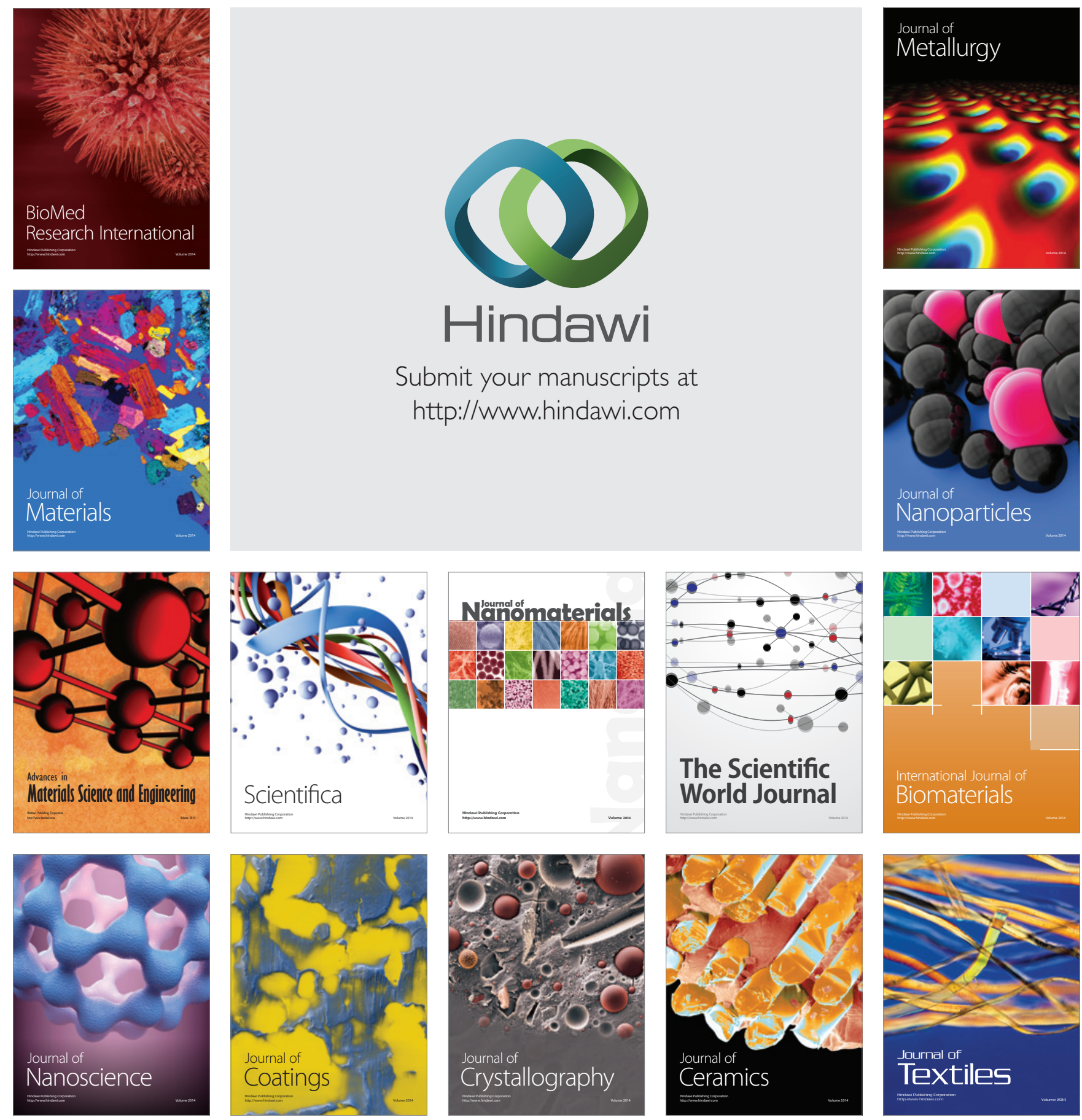